\title{
Computer-aided design of a coffee-dragging device
}

\section{Desenvolvimento de um dispositivo de derriça de café com o auxílio de programa computacional}

\author{
Marcus Vinicuis Morais de Oliveira ${ }^{1 *}$; Mauri Martins Teixeira²; Haroldo Carlos

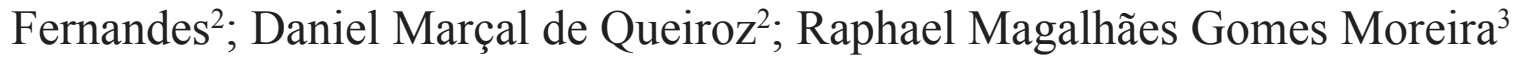

\begin{abstract}
Dragging is the most costly and time-consuming stage of the coffee harvest. Therefore, its mechanization is important. The objectives of this study were to design, build, and evaluate the dynamics of a coffeedragging device in a laboratory setting. The prototype consists of a dragging device with rods mounted on a metal plate and a chassis. Computer-aided design (CAD) software was used to generate a solid second-order tetrahedral mesh for use in finite element analyses of the device and its parts. It was possible to simulate and display the device's errors and failures and generate data on part deformities, Von Mises tension, and equivalent efforts. Equations based on the Denavit-Hartenberg theory were developed to describe the dragging device kinematics, and the results obtained with these equations were compared to those for the design developed using the software program. A preliminary drawing analysis identified a lever-type system as the best configuration for the device, based on its simple construction and its ability to balance the weight of the project parts. The safety factor achieved was greater than 28. Adjustment of the vibration amplitude of the rods is possible using the eccentric shaft of the connecting rod drive. Finite element analyses was used to analyze the connecting rod and predict the likely failure points.
\end{abstract}

Key words: Coffee Harvest, dragging prototype, CAD simulation

\section{Resumo}

\begin{abstract}
Na colheita do café a etapa de derriça é a mais onerosa e que demanda maior tempo, por isso sua mecanização torna-se tão importante. Objetivou-se com este trabalho projetar, construir e avaliar a dinâmica de um dispositivo de derriça laboratorial para café. O protótipo consta de um dispositivo de derriça com hastes montadas em uma placa metálica e um chassi. O programa computacional CAD gerou uma malha sólida tetraédrica de segunda ordem por meio de análises de elementos finitos. Foi possível simular e mostrar erros ou falhas dos dispositivos e, também gerar dados, tais como a deformação da peça, tensão de Von Mises e esforços equivalentes. Para descrever a cinemática do dispositivo de derriça, foram desenvolvidas algumas equações baseadas na teoria de Denavit-Hartenberg, que foram comparadas ao projeto desenvolvido em programa computacional. A análise dos croquis apresentou o sistema tipo alavanca como a melhor configuração para o desenvolvimento do dispositivo, por ser de simples construção e que permita facilmente equilibrar as massas das peças do projeto. $\mathrm{O}$ fator de segurança alcançado foi superior à 28 . O ajuste da amplitude de vibração das hastes foi possível com o eixo excêntrico de acionamento da biela. O estudo da biela e a previsão dos pontos de falha foi possível pela análise em elementos finitos.
\end{abstract}

Palavras-chave: Colheita de café, protótipo de derriça, simulação em CAD

1 Prof., Universidade Rural do Rio de Janeiro, UFRRJ, Seropédica, RJ, Brasil. E-mail: oliveiraufrrj@gmail.com

2 Profs., Universidade Federal de Viçosa, UFV, Viçosa, MG, Brasil. E-mail: mauri@ufv.br; haroldo@ufv.br; queiroz@ufv.br

3 Prof., Instituto Federal do Espírito Santo/Campus Itapina, IFES, Colatina, ES, Brasil. E-mail: raphael.moreira@ifes.edu.br

* Author for correspondence 


\section{Introduction}

Brazil is the largest producer and exporter of coffee and the second largest worldwide consumer of coffee (CONAB, 2010; SOUZA; QUEIROZ; RAFULL, 2006). The heterogeneity and complexity of the Brazilian coffee production are advantages in comparison to coffee production in other countries. However, producing a wide variety of coffee flavors does result in some disadvantages because of the different technological needs of different coffee varieties during both the harvest and post-harvest (RUGANI; SILVEIRA, 2006). Only with appropriate production techniques is it possible to produce highquality coffee. Coffee is an agricultural product whose value is based on qualitative parameters that determine its price and can vary considerably, depending on their management (SILVA et al., 2011; AFONSO JÚNIOR; OLIVEIRA FILHO; COSTA, 2006; SAATH et al., 2010). Therefore, a broad knowledge of coffee cultivation is essential to the machinery designer.

Labor shortages in rural areas, increases in crop-growing areas, and the need for reductions in processing times have led to an increased demand for mechanization in coffee production (MAGALHÃES et al., 2006). In a country such as Brazil, which is a leading coffee producer, research institutions and the national coffee industry must find solutions to these problems. The agricultural machinery industry has a trajectory that differs from that of the agricultural crop processing industry. The latter follows a fairly constant growth trend, whereas the industrial output of agricultural machinery is characterized by large variations not only over time but throughout the year (HARO; RUAS, 2009; GAITHER and FRAZIER, 2005; SCHEFFER; CARIO; NICOLAU, 2008).

The use of computer software has proven to be an important tool in the development of success and reliability of successful and reliable products, offering countless possibilities for assessing the technical and economic viability of products without physical models needing to be built (MAGALHÃES et al., 2006). The use of computeraided design (CAD) makes it possible to reduce costs and increase safety by facilitating the prediction of possible operational and material failures.

The use of CAD results in safer, more productive, and more cost-effective agricultural machinery design, which yields savings in both the cost and time involved in creating a design (MUNDIM et al., 2003; SHIGLEY; MISCHKE; BUDYNAS, 2004; MINETTE et al., 2008; SANTOS et al., 2008). Using CAD software, design errors can be detected that might not otherwise be noticed in the early stages of manufacture, including errors that could compromise engine life or cause fatigue failure of some engine parts (FREITAS; BEZERRA; VIEIRA, 2010). The objectives of this study were to design and build a dragging device for mountain coffee harvesting using CAD software, conduct a kinematic evaluation of the device design, and identify the parameters that are key to operational improvements on coffee plantations.

\section{Materials and Methods}

A coffee-dragging device was developed at the Laboratory of Agricultural Mechanization of the Department of Agricultural Engineering in the Federal University of Viçosa/Minas Gerais - Brazil. ACAD program was used to generate initial sketches of the device. Based on the initial sketches, it was decided to use a system of rods supported by a lever, powered by a connecting rod crank, and coupled to an eccentric shaft to produce oscillations. Using the CAD program, all of the parts of the device were designed and rendered with the physical properties of the material with which the device would be built. Carbon steel was used for most of the parts. The material property values used were obtained from the program library and are shown in Table 1. 
Table 1. Properties of the material (carbon steel).

\begin{tabular}{lcc}
\hline PROPERTIES & UNITS & VALUE \\
\hline Modulus of elasticity & $\mathrm{N} \cdot \mathrm{m}^{-2}$ & $2.1 \mathrm{e}^{+11}$ \\
Poisson's ratio & - & 0.28 \\
Modulus of rigidity & $\mathrm{N} \cdot \mathrm{m}^{-2}$ & $7.9 \mathrm{e}^{+10}$ \\
Specific mass & $\mathrm{kg} \cdot \mathrm{m}^{-3}$ & 7800 \\
Resistance to traction & $\mathrm{N} \cdot \mathrm{m}^{-2}$ & $3.99 \mathrm{e}^{+08}$ \\
Flow limit & $\mathrm{N} \cdot \mathrm{m}^{-2}$ & $2.20 \mathrm{e}^{+08}$ \\
\hline
\end{tabular}

Source: Elaboration of the authors.

After some adjustments, each part of the device was redesigned, and some of the parts were subjected to static distortion testing to improve the safety of the machine. The parts were then connected with perfect fit with respect to the joints and movement restrictions so that the CAD program could be used to analyze the device kinematics. A similar analysis was performed by Alutei, Tatar and Maties (2011) to determine the maximum forces on a robot's joints.

After the device was assembled, the CAD program "Study" was used to perform a statistical analysis. The results of the statistical analysis were used to simulate and display possible errors and device failures. This program was also used to generate data on part distortion, Von Mises tension, and equivalent strain, in a manner similar to that used in a study by Albiero, Maciel and Gamero (2011). The Von Mises tension is a criterion for determining material strength limitations. The forces applied were determined as a function of engine power, torque, and angular velocity, according to Equation 1 , which describes the strength based on engine information.

$$
F=\frac{P}{d \omega}
$$

where:

$\mathrm{F}=$ force, $\mathrm{N}$;

$\mathrm{P}=$ Engine power, $\mathrm{W}$;

$\mathrm{d}=$ displacement on the eccentric shaft, $\mathrm{m}$; and

$\omega=$ angular velocity, $\operatorname{rad} \cdot \mathrm{s}^{-1}$.

The same program was used to generate a second-order solid tetrahedral finite element mesh, the main characteristics of which are presented in Table 2.

Table 2. Properties of the mesh generated for the connecting rod study.

\begin{tabular}{|c|c|c|c|c|c|c|c|c|}
\hline $\begin{array}{l}\text { Type of } \\
\text { mesh }\end{array}$ & $\begin{array}{l}\text { Smooth } \\
\text { surface }\end{array}$ & $\begin{array}{c}\text { Mesh } \\
\text { generator used }\end{array}$ & $\begin{array}{c}\text { Jacobian } \\
\text { verification }\end{array}$ & $\begin{array}{l}\text { Element } \\
\text { size }\end{array}$ & Tolerance & Quality & $\begin{array}{c}\text { Number of } \\
\text { elements }\end{array}$ & $\begin{array}{c}\text { Number of } \\
\text { nodes }\end{array}$ \\
\hline $\begin{array}{l}\text { Solid } \\
\text { mesh }\end{array}$ & Activated & Standard mesh & 4 points & $\begin{array}{c}3.9496 \\
\mathrm{~mm}\end{array}$ & $0.19748 \mathrm{~mm}$ & High & 8472 & 14715 \\
\hline
\end{tabular}

Source: Elaboration of the authors.

The connecting rod and lever were analyzed using a static analysis; a solid mesh; the "FFEPlus" solver; and deactivation of the in-plane effect of the soft coil, of friction, of inertial attenuation, of fluid pressure effects in the Solid Works Simulation Xpress analysis package. The "Ignore clearance" button for surface contact and the adaptive method analysis option were also deactivated. Table 3 shows the material properties used for analysis of the connecting rod, and Tables 4 and 5 show the material properties and mesh properties used for analysis of the lever. 
Table 3. Material properties used for the connecting rod study.

\begin{tabular}{cccc}
\hline Name of the property & Units & Value & Value type \\
\hline Modulus of elasticity & $\mathrm{N} \cdot \mathrm{m}^{-2}$ & $2.1 \mathrm{e}^{+011}$ & Constant \\
Poisson' ratio & $\mathrm{NA}$ & 0.28 & Constant \\
Modulus of rigidity & $\mathrm{N} \cdot \mathrm{m}^{-2}$ & $7.9 \mathrm{e}^{+010}$ & Constant \\
Specific mass & $\mathrm{kg} \cdot \mathrm{m}^{-3}$ & 7800 & Constant \\
Resistance to traction & $\mathrm{N} \cdot \mathrm{m}^{-2}$ & $3.9983 \mathrm{e}^{+008}$ & Constant \\
Flow limit & $\mathrm{N} \cdot \mathrm{m}^{-2}$ & $2.2059 \mathrm{e}^{+008}$ & Constant \\
Thermal conductivity & $\mathrm{W} \cdot(\mathrm{m} \cdot \mathrm{K})^{-1}$ & 43 & Constant \\
Specific heat & $\mathrm{J} \cdot(\mathrm{kg} \cdot \mathrm{K})^{-1}$ & 440 & Constant \\
\hline
\end{tabular}

Source: Elaboration of the authors.

Table 4. Material properties used in the lever study.

\begin{tabular}{cccc}
\hline Name of the property & Units & Value & Value type \\
\hline Modulus of elasticity & $\mathrm{N} \cdot \mathrm{m}^{-2}$ & $2.1 \mathrm{e}^{+011}$ & Constant \\
Poisson's ratio & $\mathrm{NA}$ & 0.28 & Constant \\
Modulus of rigidity & $\mathrm{N} \cdot \mathrm{m}^{-2}$ & $7.9 \mathrm{e}^{+010}$ & Constant \\
Specific mass & $\mathrm{kg} \cdot \mathrm{m}^{-3}$ & 7800 & Constant \\
Resistance to traction & $\mathrm{N} \cdot \mathrm{m}^{-2}$ & $3.9983 \mathrm{e}^{+008}$ & Constant \\
Flow limit & $\mathrm{N} \cdot \mathrm{m}^{-2}$ & $2.2059 \mathrm{e}^{+008}$ & Constant \\
Thermal conductivity & $\mathrm{W} \cdot(\mathrm{m} \cdot \mathrm{K})^{-1}$ & 43 & Constant \\
Specific heat & $\mathrm{J} \cdot(\mathrm{kg} \cdot \mathrm{K})^{-1}$ & 440 & Constant \\
\hline
\end{tabular}

Source: Elaboration of the authors.

Table 5. Mesh information generated for the lever study.

\begin{tabular}{ccccccccc}
\hline $\begin{array}{c}\text { Type of } \\
\text { mesh }\end{array}$ & $\begin{array}{c}\text { Smooth } \\
\text { surface }\end{array}$ & $\begin{array}{c}\text { Mesh generator } \\
\text { used }\end{array}$ & $\begin{array}{c}\text { Jacobian } \\
\text { verification }\end{array}$ & $\begin{array}{c}\text { Element } \\
\text { size }\end{array}$ & Tolerance & Quality & $\begin{array}{c}\text { Number of } \\
\text { elements }\end{array}$ & $\begin{array}{c}\text { Number of } \\
\text { nodes }\end{array}$ \\
\hline $\begin{array}{c}\text { Solid } \\
\text { mesh }\end{array}$ & Activated & Standard mesh & 4 Points & $\begin{array}{c}9.1526 \\
\mathrm{~mm}\end{array}$ & $\begin{array}{c}0.45763 \\
\mathrm{~mm}\end{array}$ & High & 9085 & 15757 \\
\hline
\end{tabular}

Source: Elaboration of the authors.

\section{Construction of the equipment}

The device designed is essentially a cart that was built using angle outlines, in a way that permitted the installation of a $3.7-\mathrm{kW}$ electric motor in its base (Figure 1A). In the upper part, a platform was installed, and a lever was fixed to permit vibration of the rods. The front side of the cart has a system of gutters to prevent motion being caused by the plate to which the rods are fixed. To facilitate rolling on tracks, the cart was fitted with rubber tires. To vary the amplitude of displacement of the rods, an amplitude-adjustable eccentric shaft driven by the electric motor was built. A set of connecting rods and a universal joint were installed in the eccentric shaft to change and restrict the rotational movement to translation. Translational movement is produced by a universal joint and stud installed at the end of the lever and in the rods' mounting plate. This device is responsible for transmitting motion to the rods at the other end.

A mounting joint at the center of the lever was designed to be moved every time vibration of the rods is needed and is not achieved, by adjusting the eccentricity. The rods were fixed to a steel plate 
with horizontal dimensions of $350 \times 350 \mathrm{~mm}$ and a thickness of $4 \mathrm{~mm}$. In this plate, arranged in four rows and four columns, 19-mm holes were initially spaced $100 \mathrm{~mm}$ apart. Threaded bolts were welded to the plate to affix each set of rods to the plate surface.

The rods, $13 \mathrm{~mm}$ in diameter and $800 \mathrm{~mm}$ long, were made of $70 \%$ fiberglass and $30 \%$ polyester resin. The fixation bolts serve to regulate the rods' length. A Siemens Micromaster 420 frequency inverter with single-phase input and three-phase output for engines up to $5 \mathrm{KVA}$ was used to adjust the vibration frequency. An electric generator was used to power the entire system in the field. This made it possible for the dragging device to be used in areas lacking electricity, such as coffee plantations.

A set of multimeters with a data logger known as a Universal Quantity Meter (MUG) was installed to quantify the energy consumption. This instrument measures and stores data, such as electrical current, voltage, and power data. In addition to its accuracy, the MUG offers the advantage that it stores data in formats that are compatible with computer programs that can generate graphs of the energy demands of the dragging device.

Validation of the results obtained using the CAD program

A standard part was designed and analyzed in the dynamic tests performed to validate the CAD program. This part was a steel beam with a $10-\mathrm{mm}$ rectangular base, $20 \mathrm{~mm}$ in height and $100 \mathrm{~mm}$ in length. A uniformly distributed $3-\mathrm{kN}$ load was applied to the top of the beam.

The maximum deflection of the beam was calculated using Equations 2 and 3.

$$
\begin{gathered}
I=\frac{\mathbf{b h}^{3}}{12} \\
\delta_{\mathrm{Max}}=\frac{\mathrm{qL}^{4}}{8 \mathrm{EI}}
\end{gathered}
$$

where:

$\mathrm{I}=$ moment of inertia, $\mathrm{m}^{4}$;

$\mathrm{b}=$ base width, $\mathrm{m}$;

$\mathrm{h}=$ height, $\mathrm{m}$;

$\delta_{\text {Max }}=$ maximum displacement, $\mathrm{m}$;

$\mathrm{q}=$ uniform load, $\mathrm{N} \cdot \mathrm{m}^{-1}$;

$\mathrm{L}=$ beam length, $\mathrm{m}$; and

$\mathrm{E}=$ modulus of elasticity modulus, $\mathrm{N} \mathrm{m}^{-2}$.

The results obtained using Equation 3 were compared with the distortion results obtained using the CAD program.

\section{Results and Discussion}

All the device part drawings were made using rigid articulated bars so that the final system would be restricted to one degree of freedom. The device was designed with a CAD program representing the rigid bars and its joints to permit analysis of this possible movement. After analyzing the models of the previously drawn sketches, it was decided that a lever or scale system would provide the best configuration for a device that would be simple to construct and that would facilitate balancing the weight of the parts.

Once the model was established, the next step was to design the device's parts with the CAD program and then perform an analysis of the kinematics of the device. Special care was devoted to realistic modeling of the parts because some parts that were already available were used in the device. Using the CAD application assembly, the parts were joined together, taking into consideration the joints and their movement restrictions (Figure 1B), and the device kinematics were tested. With this program, it was possible to create an assembly line and perform a simulation of the device in operation. 
Figure 1. (A) prototype design produced using the CAD software and (B) design of the joints for the dragging device prototype.

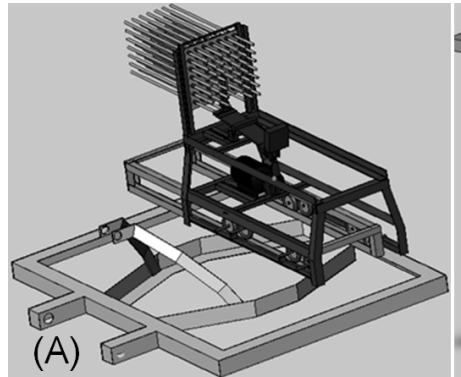

Source: Elaboration of the authors.

\section{Dynamic Testing Conducted Using the CAD Program}

The maximum forces demanded by the dragging device were determined using a $3.7-\mathrm{kW}$ electric motor, shortest minimum distance of $14.16 \mathrm{~mm}$ in the eccentric shaft, and lowest minimum angular velocity of 47,124 $\mathrm{rad} \cdot \mathrm{s}^{-1}$. Using Equation 1, a 5.77$\mathrm{kN}$ maximum force was obtained, based on the virtual resistance tests. This maximum force would only occur in the case of locking of the mechanisms by an external agent for security reasons.

The connecting rod was the first part tested with the CAD program. The results (Figure 2A, 2B, 2C and 2D) are summarized in Table 6, which also contains the results of the tension, displacement, and distortion studies. The $\mathrm{X}_{0}$ and $\mathrm{Y}_{0}$ reference points are located at the center of the part's largest hole (Figure2B). The CAD results suggest that decisions should not be made solely on the basis of the parameters of the program, so program tools that would permit reduction in either the size or the thickness of the part to meet safety limits were not used.

According to the CAD results, the flow of the material would be approximately $2.21 \mathrm{e}^{+08} \mathrm{~N} \cdot \mathrm{m}^{-2}$, while the critical point of the part would experience a maximum Von Mises tension of approximately $7.8 \mathrm{e}^{+06} \mathrm{~N} \cdot \mathrm{m}^{-2}$, resulting in a safety factor of 28.3 , during the virtual testing of the compression. The full results of the lever design analysis are presented in Table 7.

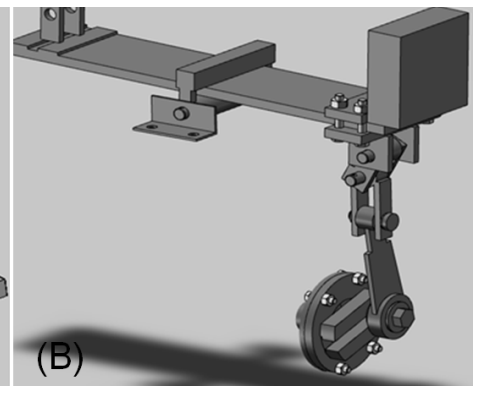

Figure 2. Results of the tension study for the connecting rod in the dragging device prototype: (A) solid tetrahedral mesh, (B) Von Mises tension, (C) displacement of the connecting rod, and (D) distortion of the connecting rod.

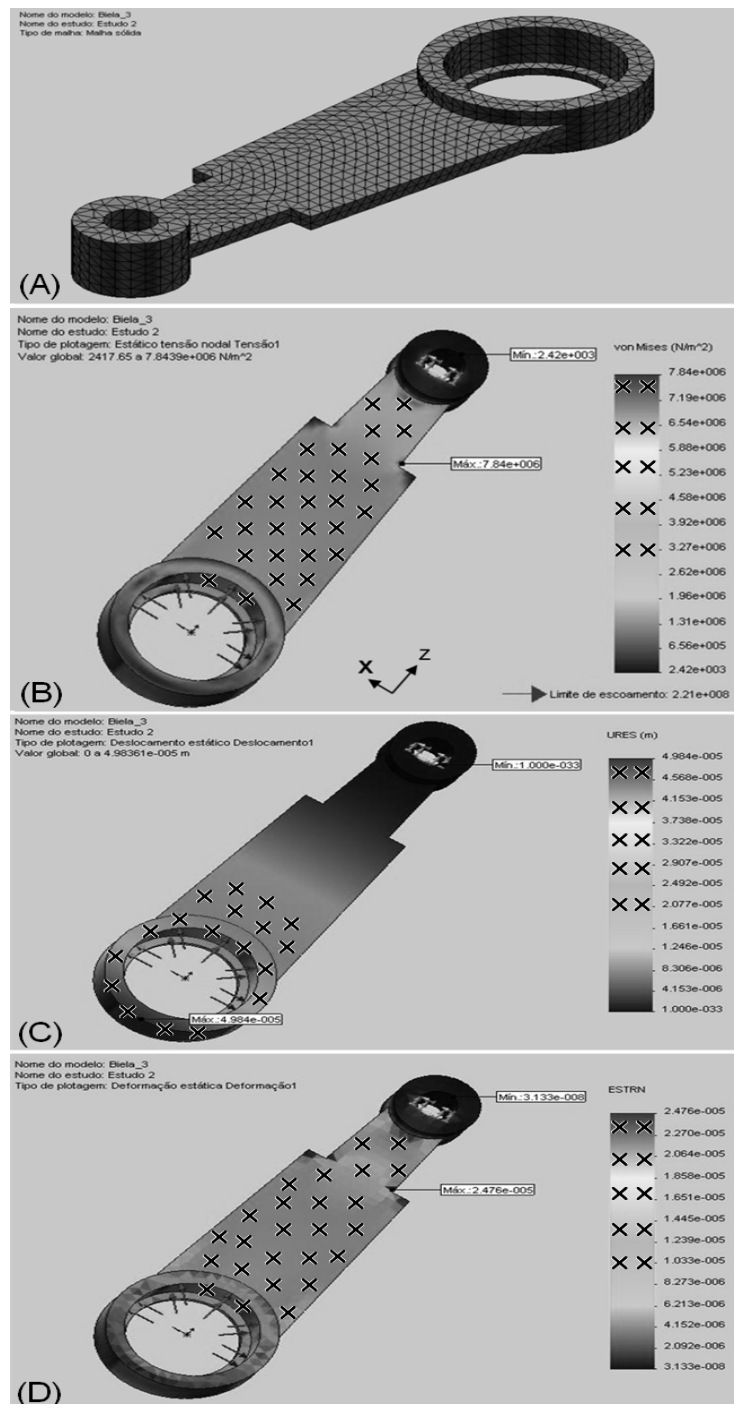

Source: Elaboration of the authors. 
Validation of the results obtained by the CAD program

Figure 3 shows the distortion results obtained from the dynamic analysis of the standard part in the CAD program. The predicted maximum deformation was $2.79 \mathrm{e}^{-04} \mathrm{~mm}$. According to equation 3 , for the standard part measurements and the values given in Table 1, the maximum deflection would be $2.67 \mathrm{e}^{-04} \mathrm{~mm}$. Thus, the error in the CAD result with respect to the theoretical value is $4.3 \%$.

Table 6. Results of the dynamic test of the rod.

\begin{tabular}{|c|c|c|c|c|c|}
\hline Name: & Type & Min. & $\begin{array}{c}\text { Location } \\
(\mathbf{x}, \mathbf{y}, \mathbf{z})\end{array}$ & Max. & Location \\
\hline Tension & $\begin{array}{l}\text { Von Mises } \\
\text { tension }\end{array}$ & $\begin{array}{c}2417.652 \mathrm{~N} \cdot \mathrm{m}^{-2} \\
\text { node: } 14150\end{array}$ & $\begin{array}{c}-2.48 \mathrm{~mm} \\
-10.00 \mathrm{~mm} \\
159.86 \mathrm{~mm} \\
\end{array}$ & $\begin{array}{c}7.84 \mathrm{e}^{+006} \mathrm{~N} \cdot \mathrm{m}^{-2} \\
\text { node: } 13079\end{array}$ & $\begin{array}{c}-13.90 \mathrm{~mm} \\
3.00 \mathrm{~mm} \\
103.88 \mathrm{~mm} \\
\end{array}$ \\
\hline Displacement & $\begin{array}{c}\text { Resulting } \\
\text { displacement }\end{array}$ & $\begin{array}{c}0 \mathrm{~m} \\
\text { node: } 5616\end{array}$ & $\begin{array}{c}-7.52 \mathrm{~mm}, \\
12 \mathrm{~mm} \\
144.99 \mathrm{~mm}\end{array}$ & $\begin{array}{c}4.98 \mathrm{e}^{-005} \mathrm{~m} \\
\text { node: } 209\end{array}$ & $\begin{array}{c}3.67 \mathrm{e}^{-15} \mathrm{~mm}, \\
9.5 \mathrm{~mm}, \\
-30 \mathrm{~mm}\end{array}$ \\
\hline Distortion & $\begin{array}{l}\text { Equivalent } \\
\text { effort }\end{array}$ & $\begin{array}{c}3.13 \mathrm{e}^{-7} \\
\text { element: } 3922\end{array}$ & $\begin{array}{l}-2.11 \mathrm{~mm} \\
-9.48 \mathrm{~mm} \\
159.19 \mathrm{~mm}\end{array}$ & $\begin{array}{c}2.47 \mathrm{e}^{-05} \\
\text { element: } 3519\end{array}$ & $\begin{array}{c}-12.94 \mathrm{~mm} \text {, } \\
2.25 \mathrm{~mm}, \\
103.186 \mathrm{~mm}\end{array}$ \\
\hline
\end{tabular}

Source: Elaboration of the authors.

Table 7. Results of the dynamic test of the lever.

\begin{tabular}{|c|c|c|c|c|c|}
\hline Name: & Type & Min. & $\begin{array}{c}\text { Location } \\
(x, y, z)\end{array}$ & Max. & Location \\
\hline Tension & $\begin{array}{l}\text { Von Mises } \\
\text { tension }\end{array}$ & $\begin{array}{c}1761.99 \mathrm{~N} \cdot \mathrm{m}^{-2} \\
\text { node: } 15378\end{array}$ & $\begin{array}{l}525 \mathrm{~mm}, \\
110 \mathrm{~mm}, \\
14.5 \mathrm{~mm}\end{array}$ & $\begin{array}{c}3.91973 \mathrm{e}^{+06} \mathrm{~N} \cdot \mathrm{m}^{-2} \\
\text { node: } 6581\end{array}$ & $\begin{array}{c}253.276 \mathrm{~mm}, \\
59.5833 \mathrm{~mm}, \\
0 \mathrm{~mm}\end{array}$ \\
\hline Displacement & $\begin{array}{c}\text { Resulting } \\
\text { displacement }\end{array}$ & $\begin{array}{c}0 \mathrm{~m} \\
\text { node: } 696\end{array}$ & $\begin{array}{c}270 \mathrm{~mm}, \\
0 \mathrm{~mm}, \\
0 \mathrm{~mm}\end{array}$ & $\begin{array}{l}6.3165 \mathrm{e}^{-04} \mathrm{~m} \\
\text { node: } 209\end{array}$ & $\begin{array}{c}0 \mathrm{~mm}, \\
55 \mathrm{~mm}, \\
12.5 \mathrm{~mm}\end{array}$ \\
\hline Distortion & $\begin{array}{l}\text { Equivalent } \\
\text { effort }\end{array}$ & $\begin{array}{l}1.08403 \mathrm{e}^{-08} \\
\text { element: } 9037\end{array}$ & $\begin{array}{c}523.25 \mathrm{~mm} \\
107.708 \mathrm{~mm} \\
14.5 \mathrm{~mm}\end{array}$ & $\begin{array}{l}1.2325 \mathrm{e}^{-04} \\
\text { element: } 4905\end{array}$ & $\begin{array}{c}254.59 \mathrm{~mm}, \\
60.9979 \mathrm{~mm}, \\
1.64973 \mathrm{~mm}\end{array}$ \\
\hline
\end{tabular}

Source: Elaboration of the authors. 
Figure 3. Distortion of the standard part.
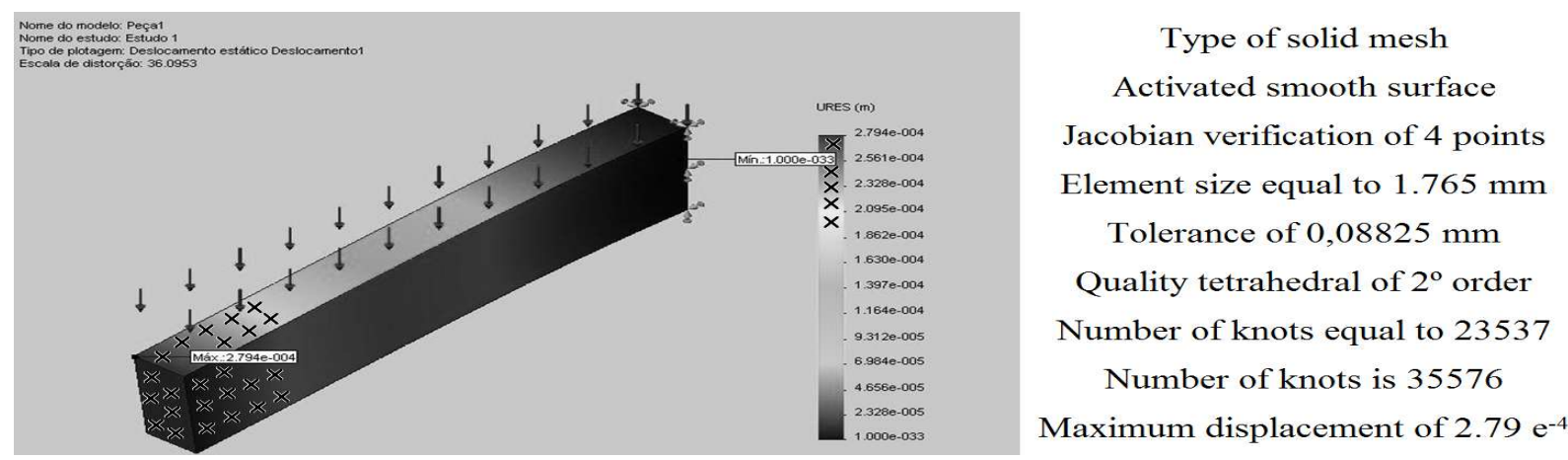

Source: Elaboration of the authors.

\section{Conclusions}

ACAD program was used to develop and evaluate a design for a coffee-dragging device. The CAD analysis results indicate that the device design has no potential critical problems, such as component failure or malfunction. The rod design tested via CAD analysis was found to have a safety factor of 28.3. The eccentric shaft of the connecting rod permits the adjustment of the vibration amplitude of the rods. The finite element mesh generated made it possible to analyze the design of the connecting rod and predict the location of the point at which failure would occur.

\section{References}

AFONSO JÚNIOR, P. C.; OLIVEIRA FILHO, D. O.; COSTA, D. R. Viabilidade econômica de produção de lenha de eucalipto para secagem de produtos agrícolas. Engenharia Agrícola, Jaboticabal, v. 26, n. 1, p. 28-35, 2006.

ALBIERO, D.; MACIEL, A. J. da S.; GAMERO, C. A. Desenvolvimento e projeto de colhedora de babaçu (Orbignya phalerata Mart.) para agricultura familiar nas regiões de matas de transição da Amazônia. Acta Amazonica, Manaus, v. 41, n. 1, 57-68, 2011.

ALUTEI, A.; TATAR, M. O.; MATIES, V. The development of a modular inspection system. The Archive of Mechanical Engineering, Warsaw, v. 58, n. 1, p. 91-102, 2011.
COMPANHIA NACIONAL DE ABASTECIMENTO - CONAB. Ministério da Agricultura, Pecuária e Abastecimento. Acompanhamento da safra brasileira de café safra de 2009/2010, quarta estimativa, dezembro/2010. Brasília; CONAB, 2010.

FREITAS, C. A. S. de; BEZERRA, L. M.; VIEIRA, M. S. Fatigue study of the steel space trusses with staking end-flattened connections. Mecânica Computacional, Buenos Aires, v. 29, n. 10, p. 911-929, 2010.

GAITHER, N.; FRAZIER, G. Administração da produção e operações. 8. ed. São Paulo: Pioneira Thomson, 2001. $598 \mathrm{p}$.

HARO, D. G.; RUAS, R. L. A. contribuição da aprendizagem organizacional no desempenho das operações de produção: estudo de caso múltiplo no segmento automotivo. Revista Gestão Industrial, Ponta Grossa, v. 5, n. 3, p. 78-96, 2009.

MAGALHÃES, A. C.; TEIXEIRA, M. M.; COUTO, S. M.; RESENDE, R. C. de. Modelagem de máquina pneumática recolhedora de frutos de café em terreiro usando análise por elementos finitos. Engenharia Agrícola, Jaboticabal, v. 26, n. 2, p. 483-492, 2006.

MINETTE, L. J.; SOUZA, A. P. de; SILVA, E. P. da; MEDEIROS, N. M. Postos de trabalho e perfil de operadores de máquinas de colheita florestal. Revista Ceres, Viçosa, MG, v. 55, n. 1, p. 66-73, 2008.

MUNDIM, J. L. C.; SOUZA, C. M.A.; QUEIROZ, D. M.; NARICI, A. A. F. Simulação do comportamento dinâmico do sistema de vibração de dois sistemas de limpeza. In: CONGRESSO BRASILEIRO DA SOCIEDADE BRASILEIRA DE INFORMÁTICA APLICADA À AGROPECUÁRIA E À AGROINDÚSTRIA, 4., 2003, Porto Seguro. Anais... Porto Seguro: Embrapa Instrumentação, 2003. p. 1-5. 
RUGANI, F. do L.; SILVEIRA, S. de F. R. Análise de risco para o café em Minas Gerais. Revista de Economia e Agronegócio, Viçosa, v. 4, n. 3, p. 343-364, 2006.

SAATH, R.; BORÉM, F. M.; ALVES, E.; TAVEIRA, J. H. da S.; MEDICE, R.; CORADI, P. C. Microscopia eletrônica de varredura do endosperma de café (Coffea arabica L.) durante o processo de secagem. Ciência Agrotécnica, Lavras, v. 34, n. 1, p. 196-203, 2010.

SANTOS, P. M. dos; SCHLOSSER, J. F.; ROMANO, L. N.; ROZIN, D.; TURATTI, J. da C.; WITTER, M. Prioridades de requisitos para projeto de postos de operação de tratores quanto à ergonomia e segurança. Pesquisa Agropecuária Brasileira, Brasília, v. 43, n. 7, p. 869-877, 2008.

SCHEFFER, J.; CARIO, S. A. F.; NICOLAU, J. A. Capacitação tecnológica de micro e pequenas empresas em arranjos produtivos locais: um estudo no segmento de materiais plásticos. RAC-Eletrônica, Rio de Janeiro, v. 2, n. 1, p. 20-36, 2008.
SHIGLEY, J. E.; MISCHKE, C. R.; BUDYNAS, R. G. Mechanical engineering design. $7^{\text {th }}$ ed. New York: McGraw-Hill, 2004. 953 p.

SILVA, G. B.; ROLIM, M. M.; PEDROSA, E. M. R.; BEBÉ, F. V.; SILVA, E. F. F. Efeito da aplicação de água residuária da lavagem dos frutos de café sobre as propriedades químicas do solo. Engenharia Agrícola, Jaboticabal, v. 31, n. 1, p. 158-166, 2011.

SOUZA, C. M. A. de; QUEIROZ, D. M. de; RAFULL, L. Z. L. Derriçadora portátil na colheita total e seletiva de frutos do cafeeiro. Pesquisa Agropecuária Brasileira, Brasília, v. 41, n. 11, p. 1637-1642, 2006. 
